\title{
Possibilities of Using Artificial Intelligence Applications in Land Consolidation Studies: Amasya Province Gümüşhacıköy District, Keçiköy Town Application
}

\section{Filiz Akin ${ }^{1 *}$ and Kadir Ersin Temizel ${ }^{2}$}

${ }^{1}$ Department of Field Crops, Bati Akdeniz Agricultural Research Institute, Antalya, Turkey

${ }^{2}$ Department of Agricultural Structures and Irrigation, Ondokuz Mayis University, Samsun, Turkey

*Corresponding Author: Filiz Akın, Department of Field Crops, Bati Akdeniz Agricultural Research Institute, Antalya, Turkey.
Received: June 24, 2021

Published: September 25, 2021

(C) All rights are reserved by Filiz Akin and

Kadir Ersin Temizel.

\section{Abstract}

In this study, the applicability of the fuzzy logic method, which is one of the artificial intelligence methods, in the distribution phase of the land consolidation study was investigated. Fuzzy logic, one of the artificial intelligence methods, has been applied to the "distribution" stage, which is the most important stage of land consolidation studies. Obtained as a result of distribution the values obtained were compared with the result of the distribution based on the interview obtained from the General Directorate of Agricultural Reform. When the results are evaluated, the number of parcels, average parcel size, time spent for new distribution, and labor force yielded better results in the fuzzy logic based distribution model.

In general, the number of parcels decreases by $40 \%$ as a result of land consolidation. In the study, it was stated that the number of parcels decreased by $35.9 \%$ in the interview-based distribution model, while this ratio was 38.2\% in the fuzzy logic-based distribution model. When both distributions were evaluated in terms of average parcel size, the average parcel size increased by $13.4 \%$ in the interview-based distribution, while it was $24 \%$ in the fuzzy logic-based distribution model. The reason for the low average parcel sizes in the results is that there are few parcels in the study area. In addition, the time spent for fuzzy logic-based distribution is $53 \%$ of the time spent for interview-based distribution.

Keywords: Land Consolidation; Parceling; Interview Based Distribution; Fuzzy Logic

\section{Introduction}

The main means of production of the villagers, who make up almost half of the population in our country, is land. The imbalance in the distribution of land in terms of ownership, the steady increase in the number of landless families, and the increasing division of land into smaller parts due to inheritance causes a significant proportion of the farmer families to use backward methods in small enterprises. This structure causes low productivity in agriculture and insufficient social development [1]. This situation reveals the existence of a socioeconomic problem in rural areas that includes all physical factors and soil-human relations. Solving this problem necessitates a comprehensive land arrangement in rural areas [2]. The purpose of land consolidation is not only to serve agriculture, but also to serve the environment, nature protection 
and regional development. These three basic tasks are divided into sub-tasks according to the needs of the countries. Preservation of rural appearance and character, thus plant and animal presence in environmental protection [3]. Consolidation studies aim to develop agriculture in the first place, to increase agricultural products in terms of quantity and quality, to economize the labor force in agriculture and finally to increase the net income of agricultural enterprises [4]. Thus, by improving different production factors, the living standards of farmer families can be increased [5].

The most important for preventing land fragmentation, collecting scattered parcels belonging to an individual, providing services such as in-field development services such as irrigation, drainage, land leveling and soil reclamation, training of the farmer and rational regulation of agricultural enterprises within the management principles and improving the agricultural structure Land consolidation, which is one of the leading measures, is a very comprehensive study that requires a wide range of information, includes many technical studies and where many professions work interactively. For this reason, it may take a very long time to start the project and conclude it. In today's information age, it is necessary to use computer support and increase automation opportunities in these projects due to the fact that land consolidation can be completed as soon as possible, that it can benefit from less manpower, and that a large number of data can be interpreted correctly [6].

The most important step of land arrangement projects is distribution studies. Arrangement, planning of enterprises according to contemporary criteria and implementation of this plan are carried out in the distribution step. In line with the wishes of those remaining within the blocks formed by the road and irrigation network in the agricultural area, new enterprises are placed in line with their participation values. In other words, new agricultural parcels are created.

The problem encountered in land arrangement applications can be defined as the distribution of "n" cadastral parcels to "m" blocks (islands) that will be subject to implementation. For this purpose, many optimization studies based on mathematical models have been carried out for the distribution process in land arrangement projects. However, since there is no exact mathematical model for the distribution process, very different solutions have been proposed. It is stated that their success is low because verbal expres- sions and human thinking structure that affect the distribution cannot be embedded into the proposed mathematical models [7].

In this study; The applicability of the fuzzy logic method in the distribution phase of the land consolidation study has been investigated. Amasya Province Gümüşhacıköy District, Keçiköy Town land consolidation project was selected as the project area. Two different distribution methods are used for the project site. These; interview based distribution model and fuzzy logic based distribution model.

\section{Materials and Methods}

\section{Materials}

Keçiköy town of Gümüşhacıköy district of Amasya province, where continental climate is dominant, was chosen as the research area. Keçiköy town is $67 \mathrm{~km}$ from Amasya, $7 \mathrm{~km}$ from Gümüşhacıköy district, and the altitude is $810 \mathrm{~m}$ (Figure 1) (Anonymous, 2010a).

The land consolidation project aims to organize an area of 4727,928 hectares. There are 22 fixed facilities and 651 cadastral parcels within the project area (Figure 1). Average size of cadastral parcels is $7240 \mathrm{~m}^{2}$.

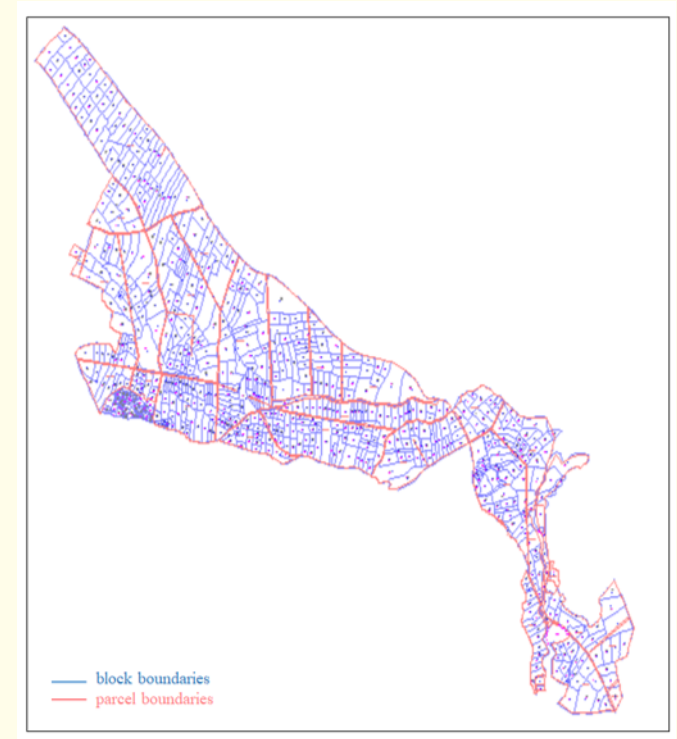

Figure 1: Cadastral status of Keçiköy town. 
The consolidation of the project area was made by the General Directorate of Agricultural Reform. The cadastral parcels of the current project, rating map, interview forms and $1 / 5000$ scale sheets were obtained from TRGM. In addition, all blocks, parcels and owners' shares in the project area were examined one by one.

\section{Methods}

In the case of land consolidation, if the distribution processes are made according to the preferences of the farmers, the name of the method is called "Interview-based distribution model". In this model, the parcels are placed in the blocks according to the first preferences of the enterprises by using the interview forms. The excesses and deficiencies in the blocks are eliminated by considering the second and third preferences of the enterprises. Then, the parcels in the block are sorted by considering their old locations and the distribution plan is obtained [8].

\section{Interview-based distribution model}

\section{Fuzzy logic based distribution model}

The fuzzy logic concept is used by Zadeh for expressions containing uncertainty. It has been put forward by expressing it mathematically. This method can also be thought of as a kind of extension of the values drawn with strict boundaries. In his article titled "Fuzzy Sets" published in 1965, Zadeh defined the fuzzy set as a set of objects with membership degrees varying in the range of [0-1]. Accordingly, it is stated that the membership degree of an element in the fuzzy set is not an absolute value and is an "interval value" between [0-1] [9]. According to the known classical set theory, the membership degrees that an element can get are 0 and 1 . That is, an element is either an element of the set (1) or not (0). While fuzzy clusters accept all shades of gray between black and white, for the classical set theory there is black and white, but no shades in between [10]. The first step of fuzzy modeling is defining the problem and choosing the appropriate parameters accordingly to determine the membership functions. is the creation. Then, the set of rules or rule base that includes the solution of the problem is created according to the relevant parameters and fuzzy subsets. In the third stage, inference methods are chosen. In the last stage, the method of rinsing the blurred value or converting it to classical numbers is determined.

\section{Fuzzy sets and degrees of membership}

In the classical concept of cluster, which works according to Aristotle's logic and has been accustomed until now, the membership degrees of the elements in a cluster are assumed to be equal to 1 if they belong there, and to 0 if they do not. In between, no membership degree can be considered. Here, in the concept of fuzzy sets, it is possible to talk about different membership degrees, ranging from 0 to 1 . Membership degrees of items in fuzzy sets take values between 0 and 1 . Fuzzy sets are an extension of classical sets; Membership degrees can take infinite values in the range of [0-1] (Figure 2). If the membership degree of an element belonging to a set is 0 , it does not belong to that set, if it is 0.3 , it belongs to that set by $30 \%$, if it is 0.7 , it belongs to that set by $70 \%$ and if it is 1 , it is said to belong to that set $100 \%$ [11].

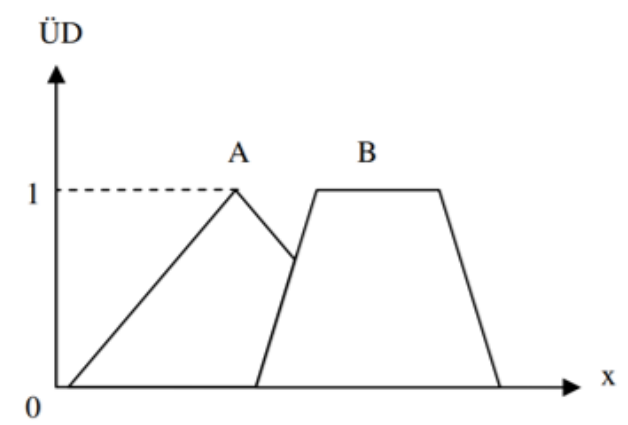

Figure 2: Fuzzy set membership degree functions.

The membership function can take different forms according to the characteristics of the process that is formally controlled. Membership functions are generally triangular, trapezoidal, and gauss (Figure 3) [7].

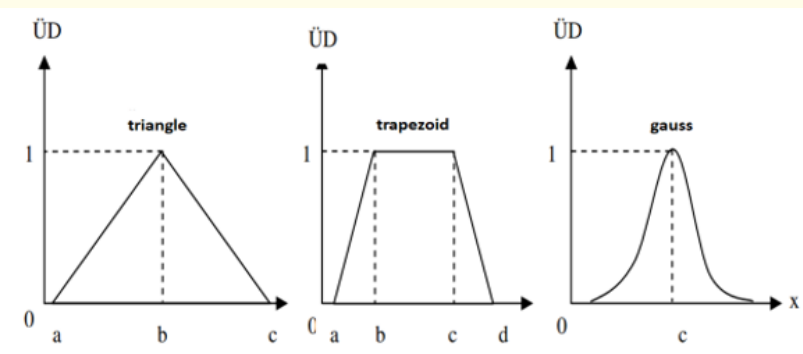

Figure 3: Various forms of membership function. 


\section{Transmission}

In general, the intervals of variation appearing as classical clusters Required for fuzzing, fuzzy set, logic and system operations. For this, it is considered that all the elements that can be in a range have different values between 0 and 1 , instead of having membership degrees equal to 1 . Some items are considered to contain uncertainty. If this uncertainty arises from non-numerical situations, it is mentioned as blurriness. In particular, in cases referred to as the sensitivity of some devices, for example, $\pm 1 \%$ accuracy means the expectation that the measured $\mathrm{x}$ magnitude will vary between $\mathrm{x}$ +0.01 and $x-0.01$. The representation of this in classical and fuzzy sets is as in figure 4 [11].

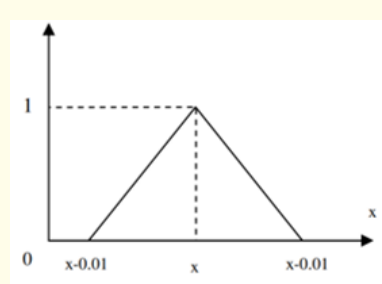

(a)

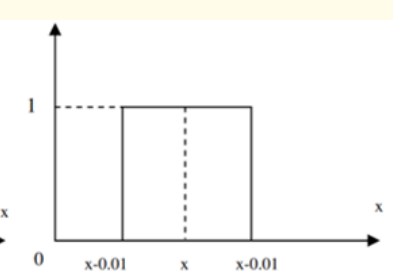

(b)
Figure 4: Sensitivity (a) fuzzy (b) classical.

\section{Fuzzy rule base}

In the field of artificial intelligence, which is the way information processes are perceived by machines, one of the different ways for information processing is to represent information with an expression similar to human language, as follows. This is the most widely used way of processing human information. Such an expression has two parts separated by the words IF-THEN. Of these, the part between IF and THEN words is "preceding terms" or "prerequisites", and the part after the word ISE is "final terms". are called "terms" or "inference". As a general rule, IF the premise is written in the form of inference. Expressions that have this kind of structure are called "IF-THEN rule-based form." If the model has "a" entries and " $b$ " membership functions, the number of rules is up to " $b^{\wedge} a$ " [12].

All of the operations performed to transform fuzzy information into definite results are called defuzzification processes [11]. The center of gravity method was used in the clarification phase of this study. It is the most widely used method in rinsing processes.

\section{Results and Discussion}

Evaluation of distribution results according to the interview model

While there were 651 parcels in Keçiköy before the land consolidation was done, 417 new parcels were created in 31 blocks as a result of the distribution based on interview method (Figure 5). The average parcel size of the parcels formed after the distribution was $8241 \mathrm{~m}^{2}$. According to the interview-based model, it takes a lot of time to examine and evaluate the interviews with farmers while creating new parceling plans.

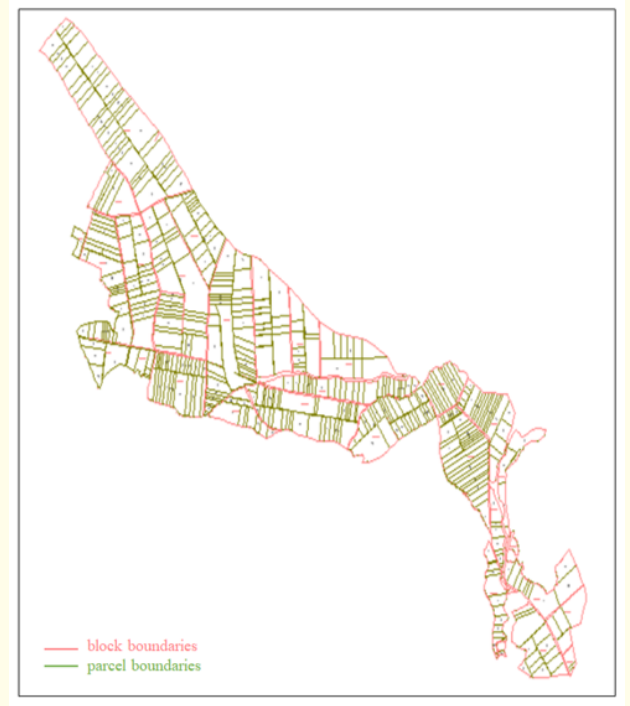

Figure 5: Parceling plan created as a result of interview-based distribution.

In the distribution phase of the land consolidation works carried out before, the first request of the farmers was to collect their fragmented land next to the largest parcel area and to gather it next to the area where the fixed facilities are located. A model was tried to be created in the fuzzy logic system by considering these two criteria (Figure 6). However, since these criteria express location information, these criteria had to be expressed in terms of angle and distance while creating the model. In other words, a criterion is expressed as two different input variables: angle and distance. Considering this information, there are four input variables in the model. Likewise, since the output value is position, there are two output variables. Fuzzy logic model was created as in figure 6. 


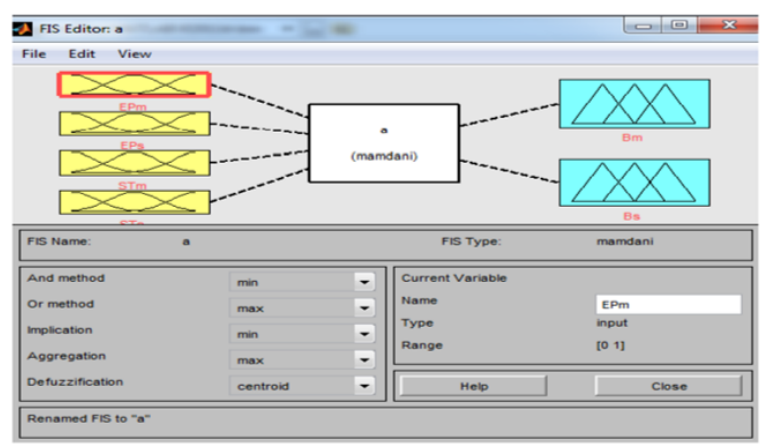

Figure 6: Fuzzy logic model and Matlab program fuzzy logic toolbox window.

As can be seen in the above figure, a fuzzy logic model with four inputs and two outputs was created: the distance of the largest parcel, the district of the largest parcel, the distance of the fixed facility, and the angle of the fixed facility.

In order to determine the membership function values of the model, a starting point that will define the project area in the Netcad environment was taken and the $\mathrm{y}$ and $\mathrm{x}$ axes were drawn from this point (Figure 7).

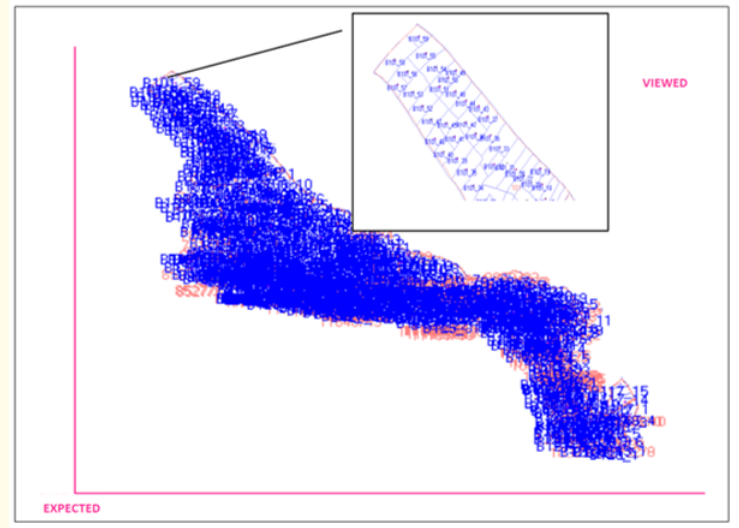

Figure 7: The starting point defining the project area.

The starting point was taken especially outside the project site and at the closest point to the site otherwise fuzzy logic will cause the system to have too much data. After determining the axis, the center of gravity of all parcels and blocks were determined in the Netcad environment and the distance and district angles were determined (Figure 8 and Figure 9).

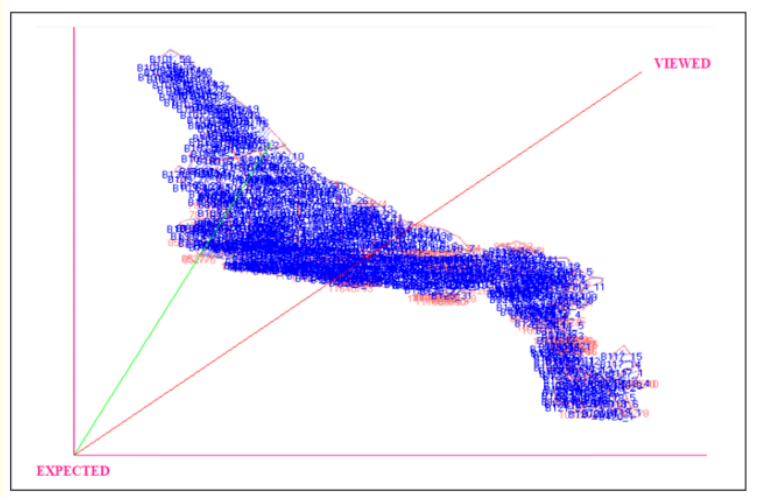

Figure 8: Display of the distance to the center of gravity of the parcel.

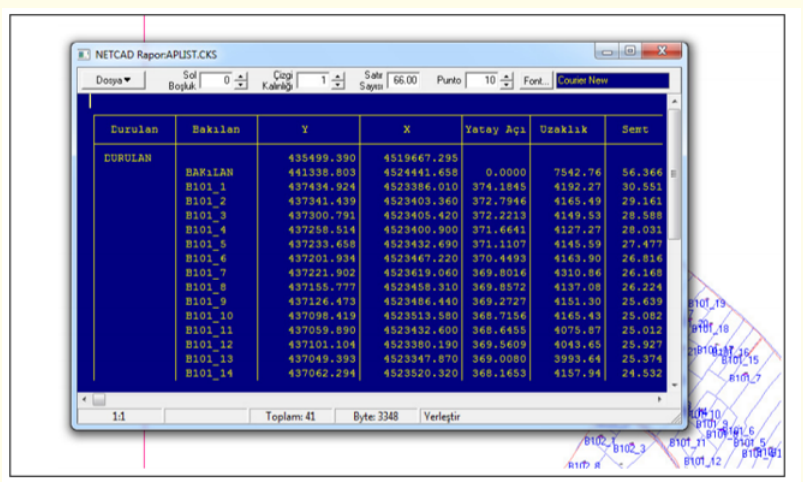

Figure 9: Finding the angle and distance values of the parcels.

In figure 8 above, a line was drawn to the center of gravity of each parcel and the district angle made by this line with the $+\mathrm{x}$ axis was found. The length of the line extending from the standing point to the center of gravity of the parcels gives the distance value. District angle and distance values of each parcel in Netcad environment has been found and reported as in Figure. 
Possibilities of Using Artificial Intelligence Applications in Land Consolidation Studies: Amasya Province Gümüşhacıköy District, Keçiköy Town Application

As can be seen in the report given in figure 9, the names of the parcels in each block and the pain and distance of all parcels are found. The distance values in the figure correspond to the distance values used in the study.

Trapezoidal and triangular membership functions are used for distance input variables (Table 1). As stated in the table, the near, far and very far expressions, which are determined as fuzzy clusters, and the function values of these expressions were determined according to the minimum and maximum values of the distance data. Trapezoid and triangular membership functions were also used for neighborhood input variables (Table 2).

\begin{tabular}{|l|c|c|}
\hline \multicolumn{3}{|l|}{ Distance } \\
\hline Fuzzy Cluster & Function Type & Function Values \\
\hline Near & trapezoid & $\begin{array}{c}-76615002827 \\
5400\}\end{array}$ \\
\hline Far & triangle & $\{410058508000\}$ \\
\hline Too far & trapezoid & $\left\{\begin{array}{c}637076009100 \\
9200\}\end{array}\right.$ \\
\hline
\end{tabular}

Table 1: Membership Function Values for Distance Input Variables.

\begin{tabular}{|c|c|c|}
\hline \multicolumn{3}{|l|}{ Semt } \\
\hline Fuzzy Cluster & Function Type & Function Values \\
\hline Narrow & Trapezoid & $\left\{\begin{array}{llll}-36 & -4 & 5 & 30\end{array}\right.$ \\
\hline Middle & Triangle & $\{103560\}$ \\
\hline Large & Triangle & $\left\{\begin{array}{llll}35 & 60 & 85\end{array}\right\}$ \\
\hline Very large & Trapezoid & $\left\{\begin{array}{lllll}60 & 80 & 110 & 150\end{array}\right.$ \\
\hline
\end{tabular}

Table 2: Membership Function Values for Zone Input Variables.

The views of the distance and district values according to the above table data from the Fuzzy Logic Toolbox window of the Matlab Program figure 10 and figure 11 shown.

There are two parts of the fuzzy rule base separated by IF-THEN (IF-THEN) words. Of these, the part between IF and ISE is called premise or prerequisites, and the part after ISE is called conclusion or inference [12]. There are four inputs and two outputs in the cre-

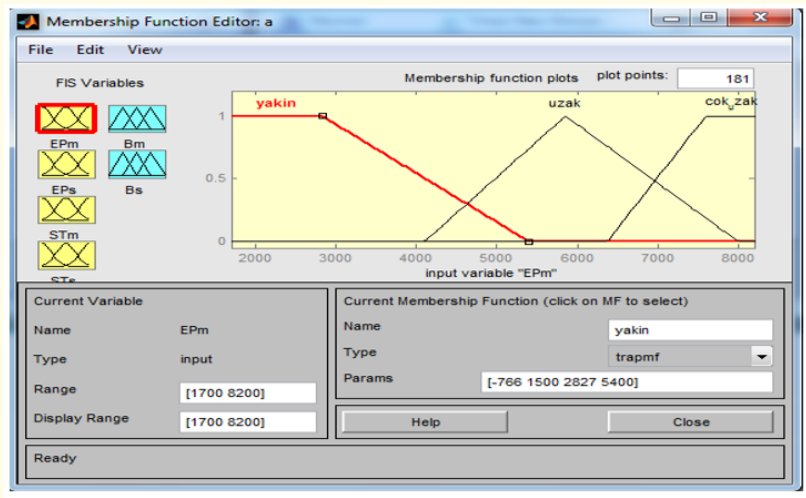

Figure 10: View of Distance Values.

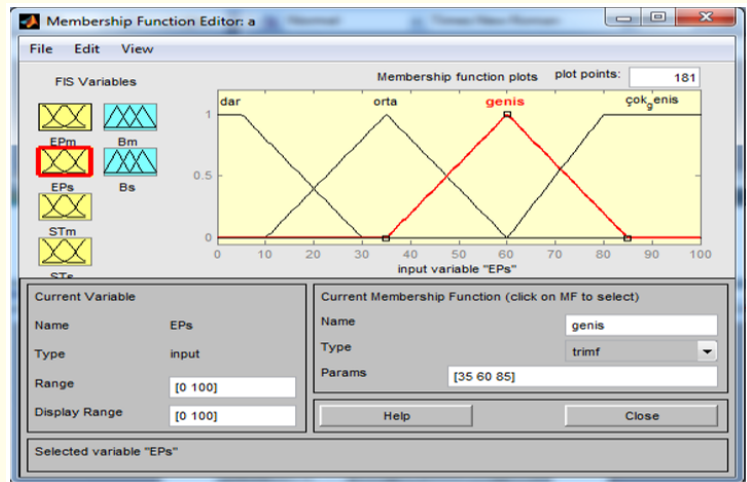

Figure 11: View of District Values.

ated fuzzy logic model. The rule base of the model consists of 144 rules.

As a result of fuzzy operations, a fuzzy set containing the structure and solution of the problem is obtained. However, in practical applications, it is desirable to obtain an exact number in order to facilitate the use of this set. The process of obtaining an odd number from the resulting fuzzy cluster after blending is called clarification [11]. In order to clarify the fuzzy output, the most common method of clarification, centroid method was used. 


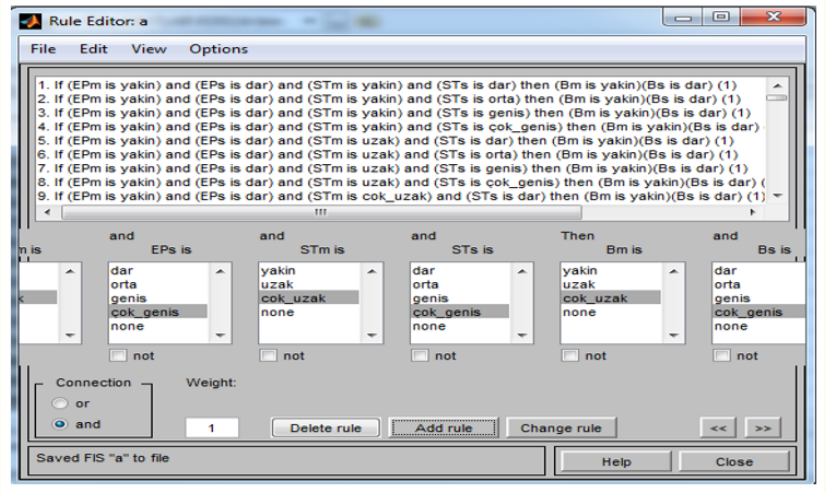

Figure 12: Rule Base of the Model.

The output values obtained are polar coordinate values. In other words, it has been obtained in terms of distance and district. The following formulas are used to convert these values to the country coordinate system.
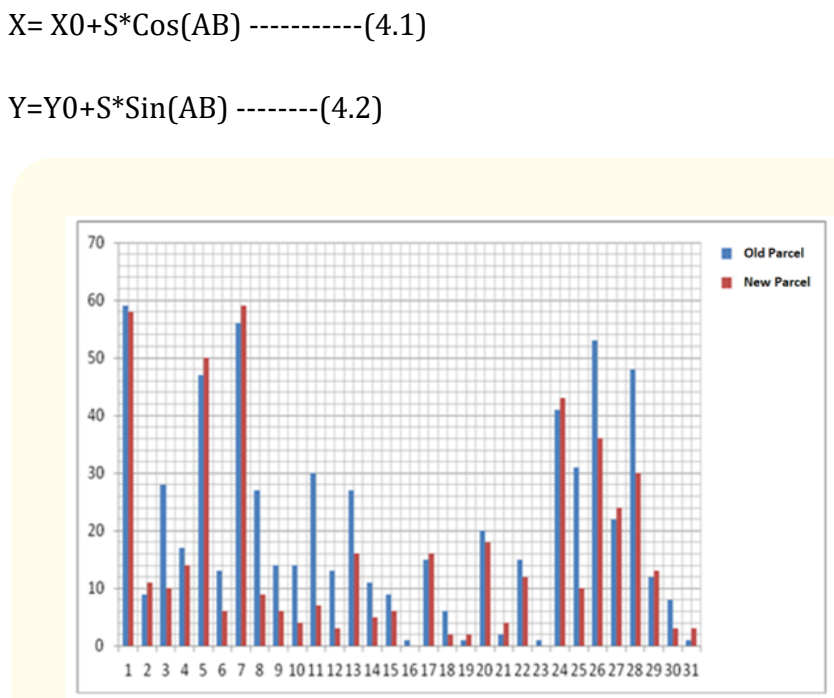

Figure 13: Display of the Occupancy Status of the Blocks.

As can be seen in the graph above, the parcels 102, 105, 107, $117,119,124,127,129$ and 131 are more than their capacity. In this case, parcels were manually shifted from filled blocks to empty blocks by looking at the parcel density, the block with the second largest parcel and the block with the third largest parcel.

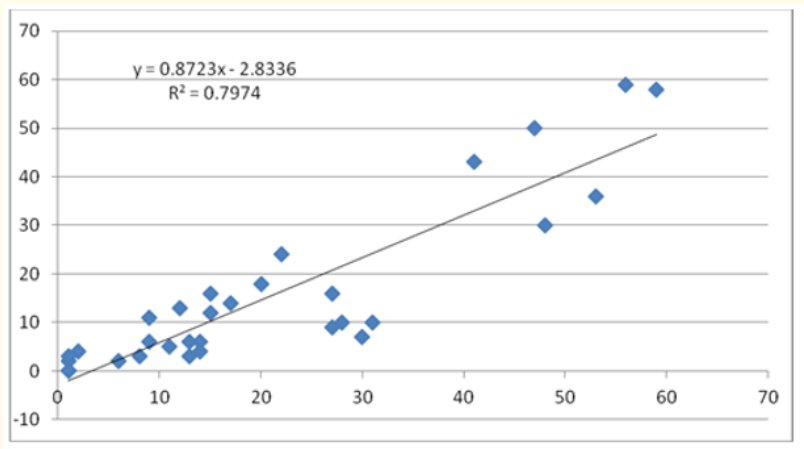

Figure 14: Regression Curve of the Model.

\section{Conclusion}

For Keçiköy Town consolidation project, fuzzy logic based distribution model was applied and compared with interview based distribution models. Fuzzy logic based distribution model has been more successful in the number of parcels. In the interview-based distribution model, the number of shares was higher than the fuzzy logic-based distribution model. When evaluated in terms of average parcel size; The parcel size formed in the fuzzy logic-based distribution model was larger than the interview-based distribution model. When evaluated in terms of distribution time and project cost; Fuzzy logic-based distribution models can be completed both at a lower cost and in a shorter time than the interview-based distribution model. When evaluated in terms of requests of businesses with their relatives; interview based distribution model gives more successful results than fuzzy logic based distribution models. Because in the interview-based model, these relationships are evaluated more easily and the wishes of the farmers are fulfilled. In the other two models, these relationships cannot be evaluated. In the fuzzy logic based distribution model, more than half of the enterprises are located in the same blocks with the interview based distribution model. Fuzzy logic based distribution model is more successful in meeting the demands of the enterprises. This situation is very important for farmers' satisfaction. Because farmer satisfaction shows the success of land consolidation.

\section{Conflict of Interest}

I declare that there is no financial interest or conflict of interest. 


\section{Bibliography}

1. Çevik B and Tekinel O. Arazi Toplulaştırması. Sulama Projelerinde Arazi Toplulaştırma Seminer Bildirileri, Devlet Su İşleri, 14-17 Kasım, Bursa (1988): 45-68.

2. Eser Ö. Gaziantep Nurdağı Gedikli Köyü Arazi Toplulaştırması Etkinliği. Kahramanmaraş Sütçü İmam Üniversitesi, Fen Bilimleri Enstitüsü, Tarımsal Yapılar ve Sulama Anabilim Dalı, Yüksek Lisans Tezi (2006).

3. Lapple EC. Europareische Fachtagung Flurbereinnigung, Z.F. Kulturtechnik und Landentwicklung 30, Verlag Paul Parej, Berlin (1989): 30.

4. Arıcı İ. Arazi Toplulaştırması. U.Ü. Ziraat Fakültesi Ders Notları, No: 60, Bursa (1994): 121.

5. Yağanoğlu AV., et al. "Arazi Toplulaştırması”. Atatürk Üniversitesi Ziraat Fakültesi Ders Yayınları No:159, Erzurum (2000): 169.

6. İşcan F. "Arazi Toplulaştırması Yazılımı İçin Algoritma Geliştirilmesi". Selçuk Üniversitesi Fen Bilimleri Enstitüsü, Jeodezi ve Fotogrametri Anabilim Dalı, Yüksek Lisans Tezi, Konya (2003).

7. İșcan F. "Arazi Düzenleme Çalışmalarında Bulanık Mantık Uygulaması". Selçuk Üniversitesi Fen Bilimleri Enstitüsü, Harita Mühendisliği Anabilim Dalı, Doktora Tezi, Konya (2009).

8. Çay T., et al. "An Investigation of Reallocation Model Based on Interview in Land Consolidation". XXIII FIG Congress Munich, Germany, October 8-13 (2006).

9. Shimoda M. "A Natural Interpretation of Fuzzy Sets and Fuzzy Relations”. Fuzzy Sets and Systems 128.2(2002):135-147.

10. Cemek B., et al. "Patlıcan Bitkisinin Sulama Programlamasının Belirlenmesinde Yapay Zeka Uygulamalarının Kullanılması”. TÜBİTAK Proje Sonuç Raporu, 1140538 (2018).

11. Şen Z. "Mühendislikte Bulanık Mantık (Fuzzy) ile Modelleme Prensipleri”. Su Vakfı Yayınları, İstanbul (2004a).

12. Şen Z. "Fuzzy Logic and System Models in Water Sciences". Su Vakfı Yayınları. 315s., Türkiye (2004b).

Volume 5 Issue 10 October 2021

(c) All rights are reserved by Filiz Akin and Kadir Ersin Temizel. 